\title{
Two new species of the genus Naviauxella Cassola, 1988 (Coleoptera: Cicindelidae) from Central Vietnam
}

\section{Ава новых вида рода Naviauxella Cassola, 1988 (Coleoptera: Cicindelidae) из џентрального Вьетнама}

\author{
A.V. Matalin ${ }^{1,2}$ \\ A.B. Маталин ${ }^{1,2}$

\begin{abstract}
1 Moscow State Pedagogical University, Education-Scientific Centre Ecology and Biodiversity, Kibalchicha str. 6, build. 2, Moscow 129164, Russia, E-mail: andrei-matalin@yandex.ru.

2 Pirogov National Research Medical University, Biology Department, Ostrovitianova str. 1, Moscow 117997, Russia.

1 Московский государственный педагогический университет, УНЦ экологии и биоразнообразия, ул. Кибальчича 6, корп. 2, Москва 129164, Россия.

2 Российский национальный исследовательский медицинский университет им. Н.И. Пирогова, кафедра биологии, ул. Островитянова, д. 1, Москва 117997, Россия.
\end{abstract}

KEY WORDS. Cicindelidae, tiger beetles, new species, Southeast Asia, Vietnam, identification keys.

КЛЮЧЕВЫЕ СЛОВА. Cicindelidae, жуки скакуны, новые виды, Юго-Восточная Азия, Вьетнам, определительные ключи.

ABSTRACT. From the Vietnamese Province Gia Lai Naviauxella fedorenkoi sp.n. and Naviauxella pseudolabiosa sp.n. are described, and how to distinguish them from related species is discussed. The revised identification keys to the species of the genus Naviauxella Cassola, 1988 are also provided.

РЕЗЮМЕ. Из вьетнамской провинции Зялай описываются Naviauxella fedorenkoi sp.n. и Naviauxella pseudolabiosa sp.n. и обсуждаются их отличия от близких видов. Предложены дополнения в опубликованные ранее определительные ключи рода Naviauxella Cassola, 1988.

The genus Naviauxella was established by Cassola [1988] and now contains 18 species distributed in Myanmar [Cassola, 1988], Thailand [Naviaux, Pinratana, 2004; Matalin, 2015], Laos [Wiesner, Geiser 2016], southern China [Shook, Wu, 2007], Vietnam [Wiesner et al., 2017] and Cambodia [Cassola, 2005; Matalin, $2018 \mathrm{a}, \mathrm{b}]$. The males of two of these species, N. labiosa Naviaux, 1996 and $N$. durandi Naviaux, 2012, are still unknown [Matalin, 2018b]. In the present paper two new species of Naviauxella are described from the Vietnamese Province Gia Lai (Central Highlands Region), and the revised identification keys to the species of this genus [Wiesner et al., 2017; Matalin, 2018b] are provided as well.

\section{Material and methods}

The specimens included in this study are housed in the collections of the Zoological Institute of the Russian Academy of Science, St.-Petersburg, Russia (ZISP), the Carnegie Museum of Natural History, Pittsburgh, USA (CMNH), the A.N. Severtsov Institute of Ecology and Evolution, Russian Academy of Sciences, Moscow, Russia (SIEE) and the Moscow State Pedagogical University, Moscow, Russia (MPU).

The measurements (in $\mathrm{mm}$ ) are as follows: total body length (TL) without labrum — from anterior margin of clypeus to elytral apex; length of labrum (LL) without apical teeth — along midline; width of labrum (LW) - in the widest place; length of pronotum (PL) - along midline; width of pronotum (PW) - in the widest place; length of elytra (EL) - from base of scutellum to apex along suture; width of elytra (EW) - in the widest place.

Species account

$$
\text { Naviauxella fedorenkoi Matalin, sp.n. }
$$
Figs 1, 4-8.

TYPE MATERIAL. Holotype - + , Vietnam, Gia Lai Province, $\sim 40 \mathrm{~km}$ NEE of Pleiku, Kon Ka Kinh National Park, $14^{\circ} 12^{\prime} 57^{\prime \prime} \mathrm{N}$ $108^{\circ} 19^{\prime} 19^{\prime \prime} \mathrm{E}, \mathrm{h}=1200 \mathrm{~m}, 9-22 . V .2016$, leg. D. Fedorenko (ZISP). DESCRIPTION. TL $-8.2 \mathrm{~mm}$ (Fig. 1).

How to cite this article: Matalin A.V. 2019. Two new species of the genus Naviauxella Cassola, 1988 (Coleoptera: Cicindelidae) from Central Vietnam // Russian Entomol. J. Vol.28. No.1. P.13-18. doi: 10.15298/ rusentj.28.1.03 
Head glabrous, bluish-black; genae bluish-green, finely striated; clypeus copper-bronze with light green tinge along anterior margin; frons purple-lilac in centre and copper-bronze on the sides, finely rugose except small smooth golden-copper tinged antennal plates; vertex bright copper-green with light golden tinge and narrow purple-lilac strip in the centre, coarsely rugose, with two prolonged impressions near anterior edge of each eye and long seta in each of them, supra-orbital plates copper with golden-green reflection, with 12 long shallow striae (Fig. 4), and a single long seta near posterior edge of each

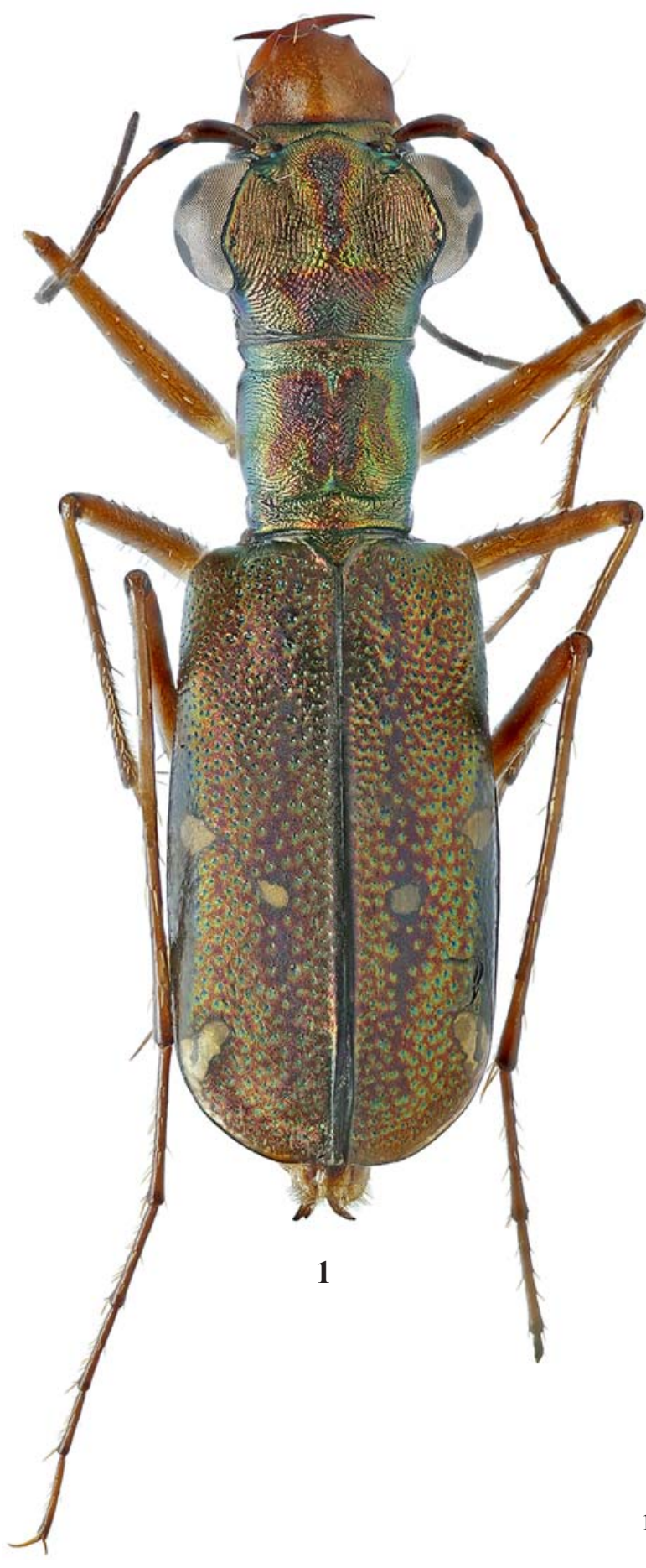

eye; occiput finely rugose, purple-lilac in the centre and copper-bronze on the sides, with golden reflection. Mandibles brownish-yellow except narrowly brownish teeth. Labial and maxillary palpi entirely pale yellow, both with more darkned apical joints. Labrum throughout covered by isodiametric microsculpture, dark yellow with narrow brownish anterior and posterior margins, transverse, 1.5 times wider than long $(\mathrm{LL}=0.8, \mathrm{LW}=1.2)$, with a broad low central carina and two shallow impressions inside it, three apical teeth and four long submarginal setae (Fig. 5). Antennae filiform, reaching back

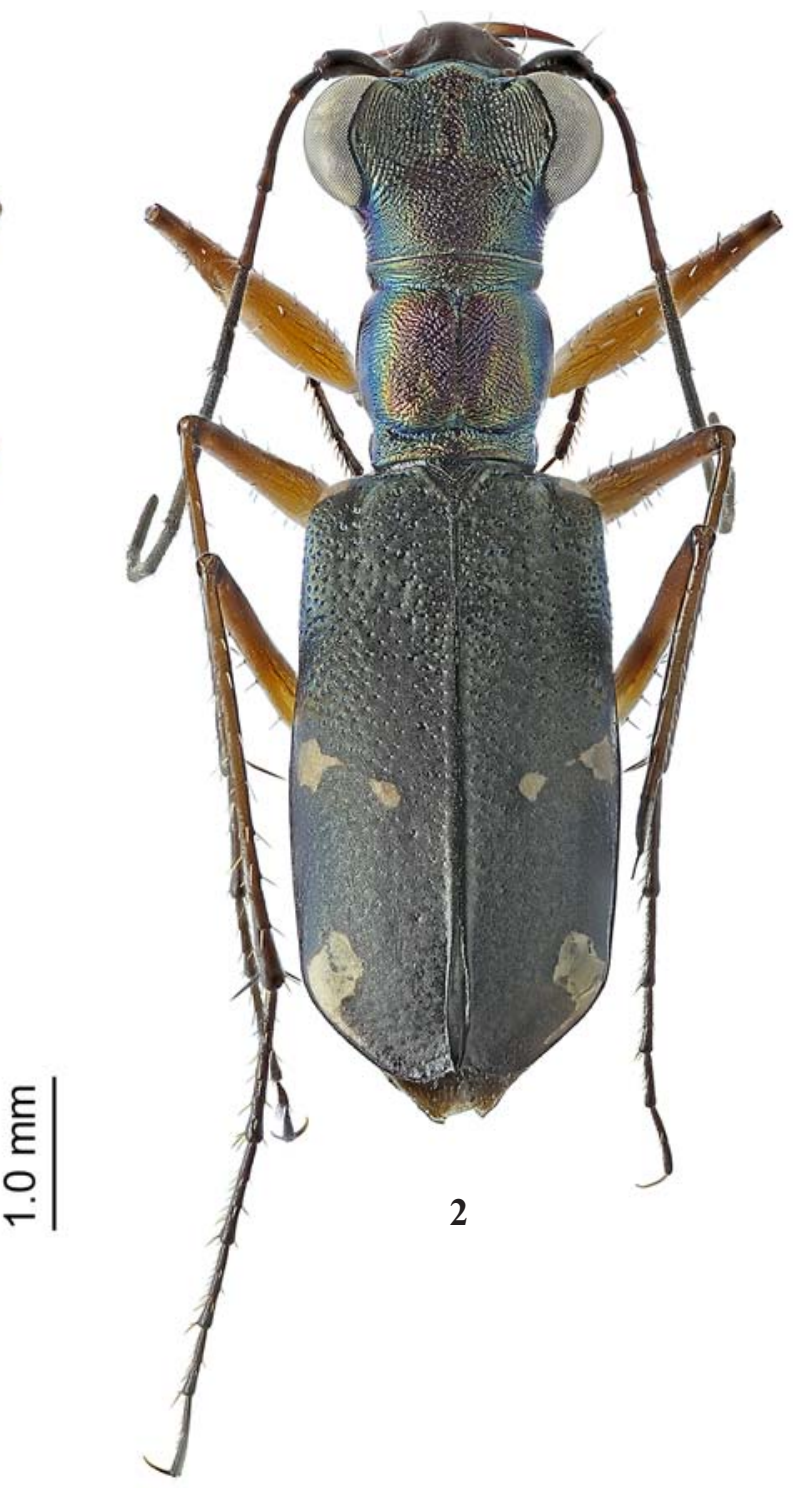

Figs 1-2. Naviauxella spp, habitus of the holotypes, dorsal view: $1-N$. fedorenkoi sp.n., female; $2-N$. pseudolabiosa sp.n., male.

Pис. 1-2. Naviauxella spp, габитусы голотипов, сверху: 1 $N$. fedorenkoi sp.n., самка; $2-N$. pseudolabiosa sp.n., самец. 
over half of elytral length; first four antennomeres light brown, with distinct greenish reflection; scape with a single long apical seta; third antennomere with three setae and fourth antennomere with one short spiniform white seta on outer side except for short apical setae; antennomeres 5-11 black, finely and regularly pubescent.

Pronotum glabrous, 1.04 times longer than wide $(\mathrm{PL}=1.45$, $\mathrm{PW}=1.4$ ), slightly rounded converging towards base lateral sides, a thin midline with short green anterior and posterior impressions, and well-marked anterior and posterior transverse grooves; pronotal disc transversely rugose, copper-bronze with golden-green reflection and bright dark purple-lilacV-shaped patch along a midline, apical and basal lobes copper-bronze (Fig. 6). Prosternum glabrous and smooth, bluish with weak metallic reflection; mesepisterna black with a single short white seta at base and deep rounded pit in basal third; metepisterna black with bluish-green tinge, indistinctly rugose, sparsely covered by short, white, appressed setae; meso- and metathorax bluish-black with light golden metallic tinge, metathorax with sparse, short, white appressed setae on sides.

Elytra 1.88 times longer than wide $(\mathrm{EL}=4.9, \mathrm{EW}=2.6)$, slightly dilated apically, with wide rounded shoulders and basal hump with a shallow depression behind, entirely covered by isodiametric sculpticells of microsculpture, background colouration copper-bronze with light purple reflection; elytral surface covered by numerous green punctures deeper in basal portion and shallow towards apical portion, lateral margin violet-blue, narrow longitudinal stripe extending from basal hump to apex purple-bronze; scutellum cop- per, finely rugulose; suture bronze in apical third clearly separated from elytral disc; epipleura in basal half brown, in apical half black; apices widely rounded and very finely microserrulate, sutural tooth very small; a white elytral pattern present in small basal portion of humeral lunula, in rounded basal and apical portions of middle band, and in basal portion of apical lunula with very long narrow sublateral portion extending practically to the suture (Figs 7-8).

Abdominal sternites glabrous, black with weak bluish tinge, sixth sternite dark-brown. Fore and middle coxae paleyellow with greenish tinge basally, anterior surface of fore, as well as anterior and posterior surfaces of middle coxae with few short white appressed setae; hind coxae metallic bluishgreen with golden reflection, with a few short white setae along lateral margin. Trochanters pale-yellow, fore trochanters with a long apical seta. Legs yellowish-brown except slightly darkened apices of tibia and each tarsomere with indistinct bluish tinge.

Male unknown.

ETYMOLOGY. In honour of Dr. Dmitryi Fedorenko, my good friend and the famous carabidologist who collected the holotype.

COMPARATIVE NOTES. Naviauxella fedorenkoi sp.n. is easily recognized from the females of other Naviauxella species with incomplete middle band by the coloration of elytra, the well marked basal portion of humeral lunula as well as the shape of apical lunula (Figs 7-8) [compare with Figs 1623 in Matalin, 2018b]. Among them N. fedorenkoi sp.n. is more similar to $N$. loebli Matalin, 2018, but in addition to

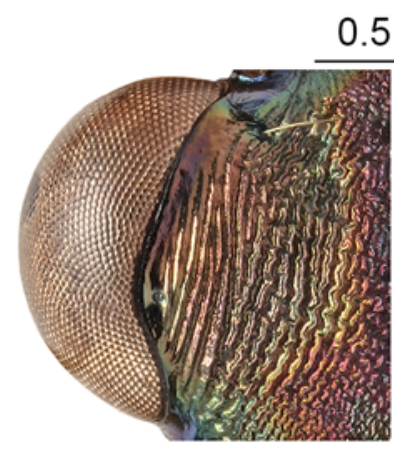

3
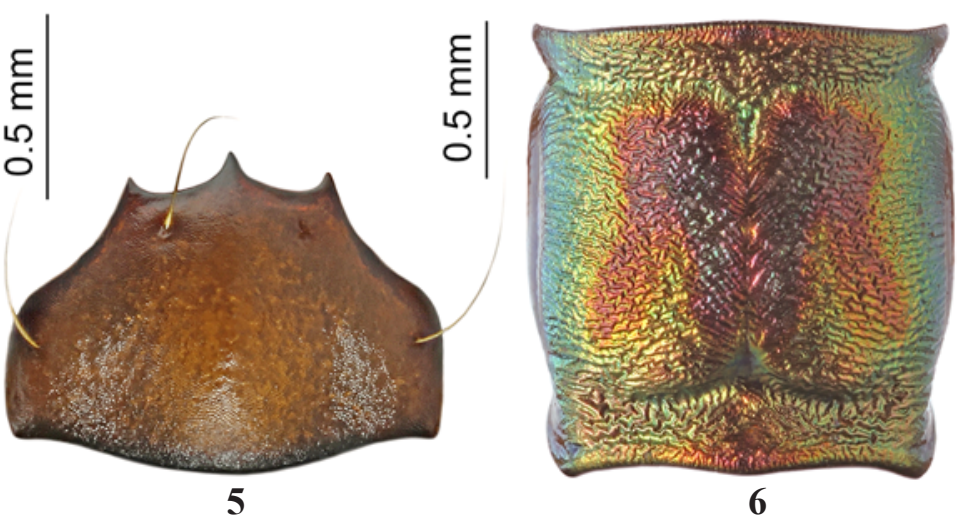

6
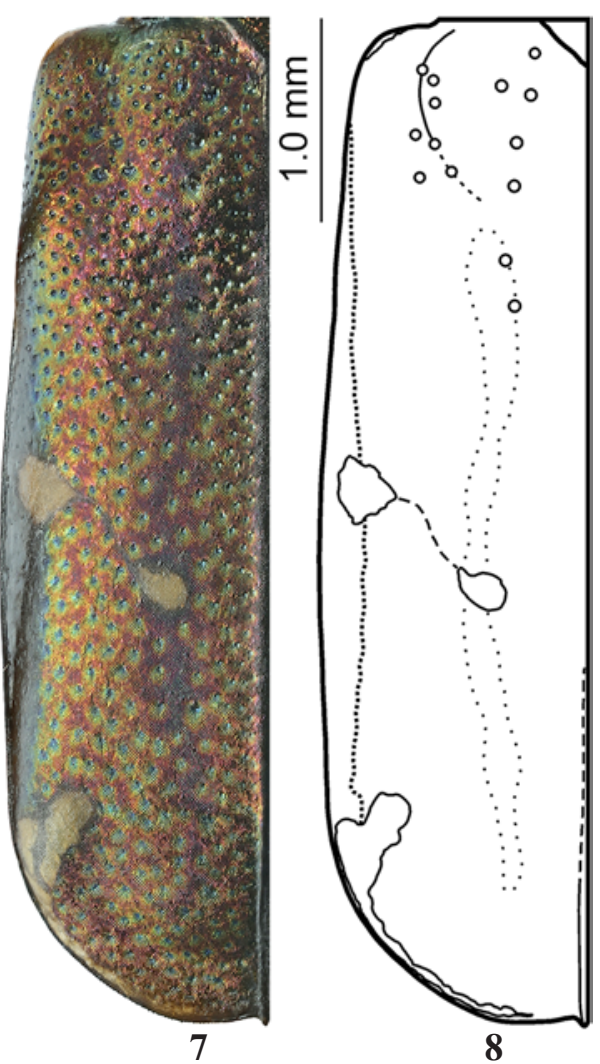

Figs 3-8. Naviauxella spp, holotypes: $3-N$. loebeli, male; $4-8-N$. fedorenkoi sp.n., female; $3-4-$ head, dorsal view $(3-$ left half, 4 - right half); 5 - labrum; 6 - pronotum; 7-8 - left elytron ( 7 - photo, 8 - drawing).

Figs 3-8. Naviauxella spp, голотипы: $3-N$. loebeli, самец; 4-8 - N. fedorenkoi sp.n., самка; 3-4 - голова, сверху (3 - левая половина, 4 - правая половина); 5 - верхняя губа; 6 - переднеспинка; 7-8 - левое надкрылье (7- фотография, 8 - рисунок). 
mentioned above features the new species differs distinctly in the finer rugosity of the supraorbital area with 16 striae (Fig. 4) vs coarser rugosity of the supraorbital area with 12 striae in $N$. loebli (Fig. 3), as well as by the shape and coloration of pronotum (Fig. 6) [compare with Fig. 3 in Matalin, 2018b].

\section{Naviauxella pseudolabiosa Matalin, sp.n.}

Figs 2, 9-10, 13, 15-18, 20-21.

TYPE MATERIAL. Holotype - $\sigma^{7}$, Vietnam, Gia Lai Province, $\sim 40 \mathrm{~km}$ NEE of Pleiku, Kon Ka Kinh National Park, $14^{\circ} 12^{\prime} 11^{\prime \prime} \mathrm{N} 108^{\circ} 18^{\prime} 54^{\prime \prime} \mathrm{E}, \mathrm{h}=890 \mathrm{~m}, 9-22 . V .2016$, leg. D. Fedorenko (ZISP); Paratypes $-20^{7} \sigma^{7} 1$, , some labeled as the holotype $\left(10^{\top} 1\right.$ 우 - MPU, $10^{x}-$ SIEE).

DESCRIPTION. TL - 6.6-7.0 $\mathrm{mm}$ in males (Fig. 2), 7.6 $\mathrm{mm}$ in female.

Head glabrous, bluish-green; genae finely striated, bluishgreen in males and bluish-violet with greenish anterior margin in female; clypeus finely wrinkled laterally, golden-green with distinct copper reflection and narrow bluish anterior and posterior margins; frons golden-green with large central purplelilac patch, distinctly rugose except small smooth bright green, blue-green or blue reflected antennal plates; vertex goldengreen with light bluish tinge and narrow purple-lilac strip in the centre, coarsely rugose, with prolonged impression near anterior edge of each eye and long seta on each of them, supraorbital plates golden-green, with 10-11 long shallow striae with straight sides in outer half and with wavy sides in the inner half (Fig. 13), with a single long seta near posterior edge of each eye; occiput finely rugose, greenish-gold with bright purple-lilac central area. Mandibles pale yellow except narrowly brownish teeth. Labial and maxillary palpi pale yellow or yellow-brown except dark-brown apical joints. Labrum throughout covered by isodiametric microsculpture, from light brown to brown in males and dark brown-black in female, transverse, 2.0-2.11 times wider than long in males ( $\mathrm{LL}=$ $0.45-0.5, \mathrm{LW}=0.9-0.95)$ and 1.83 times wider than long in female $(L L=0.6, L W=1.1)$, with four long submarginal setae, a broad low central carina, wide shallow central notch bounded by two lateral teeth in males (Fig. 9) and three apical teeth with medial tooth distinctly protruding beyond the others, and distinctly sinuate margins before outside apical teeth in female (Fig. 10). Antennae filiform, reaching over half of elytral length; first four antennomeres in males from light-brown to dark-brown with light greenish tinge, in female black-brown with distinct golden-green reflection; scape with a single long apical seta; third antennomere with three-four, while fourth antennomere with one short spiniform white seta on outer side except for short apical setae; antennomeres 5-11 black, finely and regularly pubescent.

Pronotum glabrous, nearly quadrate, $1.0-1.04$ times longer than wide $(\mathrm{PL}=1.3-1.4, \mathrm{PW}=1.25-1.4)$, converging sightly towards base, distinct rounded lateral sides in males and slightly rounded lateral sides in female, a thin shallow golden midline and well-marked bluish-green or blue anterior and posterior transverse grooves; pronotal disc transversely rugose, golden-green with purple reflection in the centre and bright V-shaped purple-lilac patch along a midline, apical and basal lobes golden-green with purple-lilac edges, lateral sides bluish-green in males and blue-violet in female (Figs 15-16). Prosternum and proepisterna glabrous and smooth, bluish-black with weak greenish reflection; mesepisterna in males blue-violet, finely wrinkled with few short white setae at base, in female bluish-black, glabrouse, with two short white seta at base and long slightly sinuated longitudinal groove with deep small oval pit in basal third; metepisterna in males greenish-blue, evenly covered by short white appressed setae, in female blue-violet with a few short white appressed setae along anterior edge only; meso- and metasternum in males greenish-blue with light golden tinge, in female bluishviolet with light greenish reflection, metasternum with sparse short white appressed setae on sides.

Elytra 1.86-1.91 times longer than wide $(E L=3.9-4.2$, $\mathrm{EW}=2.1-2.2$ in males; $\mathrm{EL}=4.7, \mathrm{EW}=2.5$ in female), indistinctly dilated apically in males and more clearly dilated in female, with rounded shoulders, low basal hump and very shallow depression behind them; elytral surface black-bronze, entirely covered by isodiametric sculpticells of microsculpture and numerous greenish-blue punctures that are deeper in basal third, shallow around middle band and practically invisible in apical half, lateral margin blue-violet; scutellum copper-bronze in some specimens with light golden-green tinge, finely rugulose; suture deep-bronze, clearly separated from elytral disc except basal quarter; epipleura light brown; apices widely and gradually rounded in males and more sharply in female; a white elytral pattern present by basal portion of humeral lunula which visible in female as very small point only in front view, by short middle band including relatively wide lateral portion and more small rounded apical portion in practically invisible in some specimens, as well as by basal portion of apical lunula which is commashaped in males (Fig. 17) and oval in female (Fig. 18).

Abdominal sternites first to fifth greenish-blue in males and blue in female, sixth sternite dark-brown, sternites third to sixth with a few short and thin white hair-like setae in the centre, fouth sternite with one pair while fifth sternite with two pairs of long thin setae along anterior margin. Fore and midddle coxae pale-yellow with greenish-blue reflection, the former with appressed white setae on anterior surface while the latter with setae on anterior and posterior sirfaces and with long single apical seta, hind coxae bluish-green with light golden reflection, with white appressed setae along lateral margin only and a single apical seta. Trochanters paleyellow, fore trochanters with a long apical seta. In males femora pale-yellow with brownish anterior surface, tibia and tarsi dark-brown with light blue metallic lustre, in female legs dark-brown except light-brown posterior surface of femora.

Aedeagus 2.0-2.1 times shorter than elytra $(\mathrm{AL}=1.9$ 2.0 ), with short basal portion and shortly tapered rounded apex with short distinct lateral carina; flagellum stout, medium long (Fig. 20-21).

ETYMOLOGY. The new species is named "pseudolabi$o s a$ " because it very similar outwardly to Naviauxella labiosa Naviaux, 1996.

COMPARATIVE NOTES. Naviauxella pseudolabiosa sp.n. is readily distinguished from other Naviauxella species by the shape of aedeagus (Fig. 21) [compare with Figs 24-39 in Matalin, 2018b] and similar to N. labiosa. As the male of $N$. labiosa is not yet known, the comparison of these species is based only on the features of the females. In N. pseudolabiosa sp.n. labrum shorter $(\mathrm{LW} / \mathrm{LL}=1.83)$ with medial tooth distinctly protruding beyond the others, and sinuate margins before outside apical teeth (Fig. 10) while in N. labiosa labrum longer and trapeziform (LW/LL $=1.70-1.73)$, with practically straight (Fig. 11) or indistinct wavy (Fig. 12) lateral margins and with medial tooth slightly protruding beyond the others; the rugosity of supraorbital area in $N$. pseudolabiosa sp.n. coarser with 14 striae (Fig. 13) while in N. labiosa the rugosity of supraorbital area finer with 16-18 striae (Fig. 14).

NOTES. The previously mentioned specimens of Naviauxella pseudolabiosa sp.n. (see type meterial) were erroneously recorded as $N$. acciavatti Naviaux, 1996 from the Vietnamese Province of Gia Lai [Wiesner et al., 2017]. 

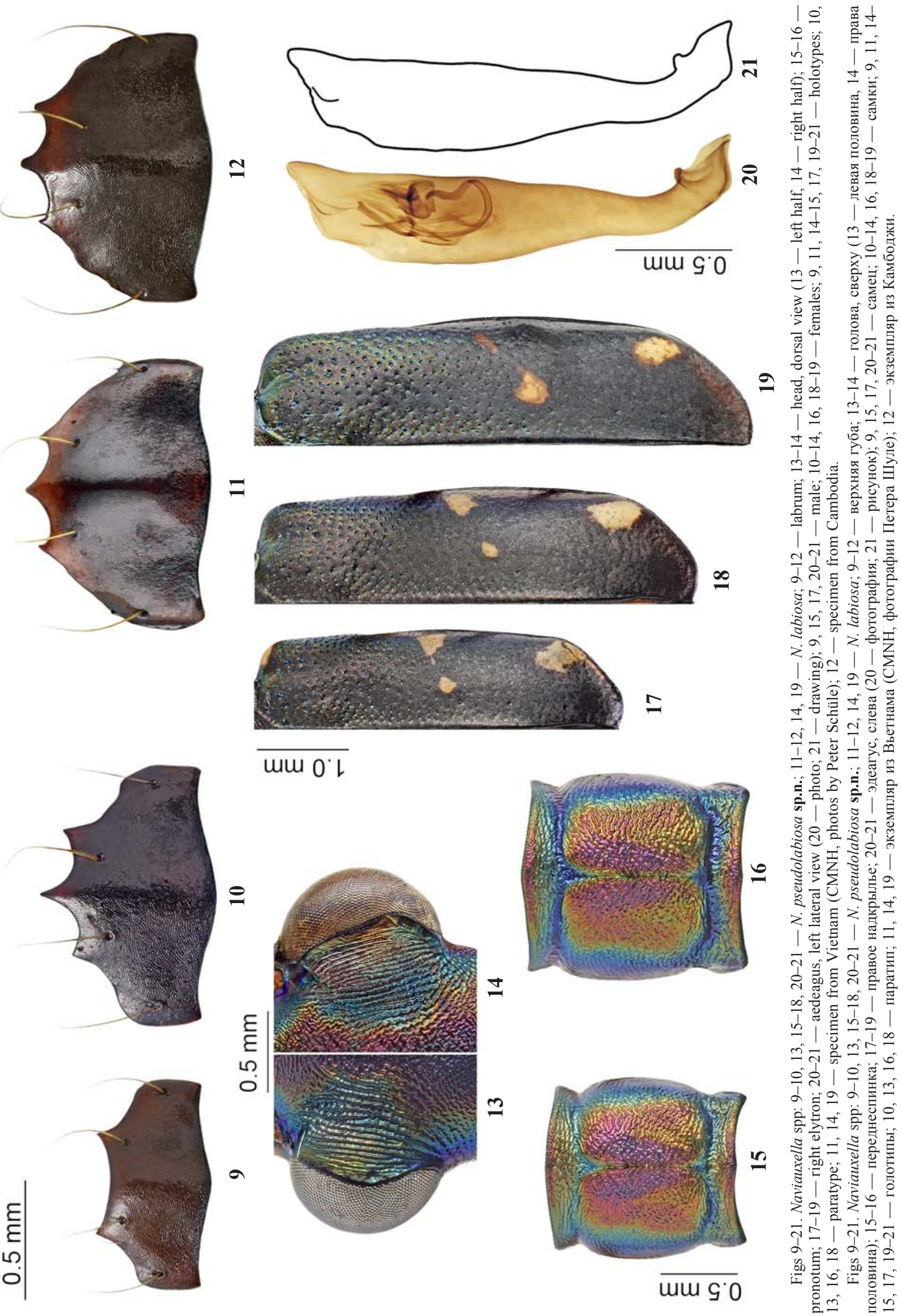

$=$
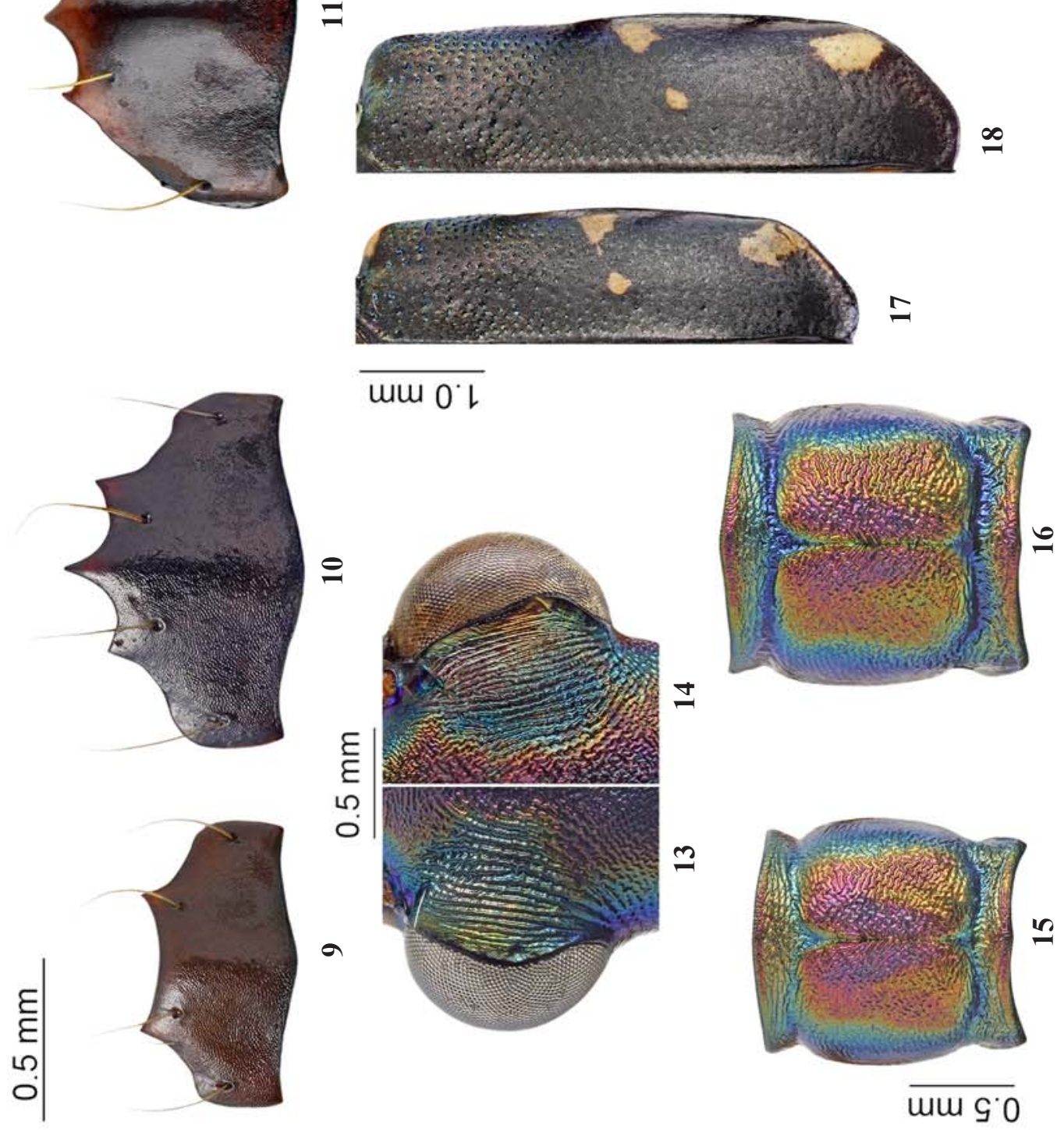

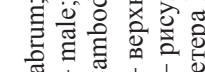

$\sim \bar{\sim} \cong \vec{\sim}$

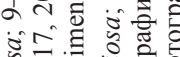
능

$z \hat{2} \mid z$ औ

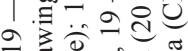

\pm 0 늠

I $\overline{\mathrm{N}}$ I 0

二oㅇ.

造家

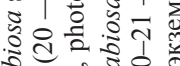

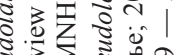

䨔纪

至|哥二

ते

赵造

$n$ 므

m금

위 1 웝

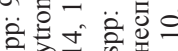

눈

1 ।

을 表示

กิำ

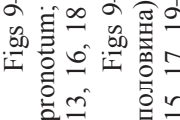


The key to Naviauxella Cassola, 1988 species of Vietnam [Wiesner et al., 2017] must be modified as follows:

1. Elytra with longitudinal brown band from base to middle lunule.

- Elytra without longitudinal brown band ...................... 3

2. Apical part of elytral middle lunule slender and descending ................... N. rufovittata Cassola et Werner, 1995

- Apical part of elytral middle lunule roundish and/or upturning ............................ N. snowiana Cassola, 2002

3. Apical lunula with very long sublateral portion practically extending suture ................................ N. fedorenkoi sp.n.

- Apical lunula with short or without sublateral portion 4

4. Labrum yellow-brown. Middle band broad .

N. acciavattii Naviaux, 1996

Labrum brown to brown-black. Middle band narrow. 5

5. Labrum with medial tooth slightly protruding beyond the others and no sinuate lateral margins before outside apical teeth .................................. N. labiosa Naviaux, 1996

- Labrum with medial tooth distinctly protruding beyond the others and sinuate margins before outside apical teeth ... N. pseudolabiosa sp.n.

The couplets $13-17$ of the key to Naviauxella Cassola, 1988 species [Matalin, 2018b] must be modified as follows:

13. Apical lunula incomplete, comma-shaped 14

- Apical lunula incomplete, oval or rounded ................ 18

14. Elytra copper-bronze .............................................. 15

- Elytra brown-black, dark bronze or black-bronze. Aedeagus with a straight ventral edge and bent ventrally apex .... 16

15. Elytra with golden-green reflection. The rugosity of supraorbital area coarser, with 12 striae. Apical lunula with short sublateral portion. Aedeagus with a small convexity on ventral side and slightly bent apex rounded dorsally N. loebli Matalin, 2018

- Elytra with light purple reflection. The rugosity of supraorbital area finer, with 16 striae. Apical lunula with very long sublateral portion practically extending suture. Male unknown $N$. fedorenkoi sp.n.

16. Aedeagus with a widely rounded blunt apex. Middle band represented by a triangular lateral spot, in some specimens by an additional small apical spot

N. shooki Wiesner, 2010

- Aedeagus with a tapered rounded apex ..................... 17

17. Elytra dark bronze. Middle band made up of two small dark yellowish spots; apical lunula small. Aedeagus with a long thin apex .............. N. declivitatis Naviaux, 1991

- Elytra black-bronze. Middle band represented by relatively large triangular lateral portion and small rounded apical spot; apical lunula large. Aedeagus with a short wide apex N. pseudolabiosa sp.n.

18. Apical portions of middle band small. Aedeagus with a short, rounded apex gradually bent ventrally N. pinratanai Naviaux, 1991

- Apical portions of middle band larger. Females .....
19. Total length no more than $7.0 \mathrm{~mm}$. Labrum shorter, entirely reddish-yellow ....... N. durandi Naviaux, 2012

- Total length more than $7.0 \mathrm{~mm}$. Labrum dark brown or black-brown .................................................... 20

20. Total length 7.4-7.8 mm. Labrum longer, 1.70-1.73 times wider than long, trapeziform, with medial tooth slightly protruding beyond the others and no sinuate lateral margins before outside apical teeth. The rugosity of supraorbital area finer, with 16-18 striae .....

N. labiosa Naviaux, 1996

- Total length $8.2 \mathrm{~mm}$. Labrum shorter, 1.83 times wider than long, with medial tooth distinctly protruding beyond the others and sinuate margins before outside apical teeth. The rugosity of supraorbital area coarser, with 14 striae N. pseudolabiosa sp.n.

Acknowledgments. I am very grateful to Dr. Dmitriy Fedorenko (Moscow, Russia) who kindly loaned the materials for this study, to Dr. Robert Davidson (Pittsburgh, USA) and Mr. Peter Schüle (Herrenberg, Germany) for the pictures of the holotypes of N. labiosa, as well as to Prof. David L. Pearson (School of Life Sciences, Arizona State University, USA, http://sols.asu.edu/index. php) for the revision of the English text.

\section{References}

Cassola F. 1988. Nota su Cicindela davisoni Gestro (Coleoptera, Cicindelidae) // Doriana, Annali del Museo Civico di Storia Naturale "G. Doria". Genova. Vol.6. No.262. P.1-6.

Cassola F. 2005. New data from Thailand and Cambodia (Coleoptera: Cicindelidae) // Bulletin de l'Institut Royal des Sciences Naturelles de Belgique, Entomologie. Vol.75. P.13-21.

Matalin A.V. 2015. New records of tiger beetles (Coleoptera, Carabidae: Cicindelinae) from Thailand // Journal of Asia-Pacific Entomology. Vol.18. No.3. P.617-627 doi: 10.1016/ j.aspen.2015.07.011.

Matalin A.V. 2018a. New records of tiger beetles (Coleoptera, Carabidae: Cicindelinae) from Cambodia // Far Eastern Entomologist. No.356. P. 9-16 doi: 10.25221/fee.356.2.

Matalin A.V. 2018b. Review of the tiger beetle genus Naviauxella Cassola, 1988 (Coleoptera, Carabidae: Cicindelinae), with the description of a new species from Cambodia // Entomologische Blätter und Coleoptera. Vol.114. P.293-299.

Naviaux R. 1996. Trois nouvelles espèces du genre Naviauxella Cassola (Coleoptera, Cicindelidae) // Revue scientifique du Bourbonnais et du centre de la France. 1996. P.65-70.

Naviaux R., Pinratana A. 2004. The tiger beetles of Thailand (Coleoptera, Cicindelidae). Bangkok: Brothers of St. Gabriel in Thailand, Sunprinting. $177 \mathrm{pp}$.

Shook G., Wu X.-Q. 2007. Tiger beetles of Yunnan. Yunnan Publishing Group Corporation: Yunnan Science \& Technology Press. 119 pp.

Wiesner J., Geiser M. 2016. Faunistic survey of the Tiger Beetles (Coleoptera, Carabidae, Cicindelinae) of Laos // Entomologica Basiliensia et Collectionis Frey. Vol.35. P.61-117.

Wiesner J., Bandinelli A., Matalin A. 2017. Notes on the tiger beetles (Coleoptera: Carabidae: Cicindelinae) of Vietnam // Insecta Mundi. No.0589. P.1-131. 